\title{
Decreased iron absorption in patients with active rheumatoid arthritis, with and without iron deficiency
}

\author{
J WEBER, ${ }^{1}$ J M WERRE, ${ }^{2}$ H W JULIUS, ${ }^{1}$ AND J J M MARX
}

From the 'Departments of Rheumatology and Internal Medicine, Hospital de Malberg GZ, Arnhem; the ${ }^{2}$ Radiological Service TNO, Arnhem; and the ${ }^{3}$ Departments of Internal Medicine and Haematology; University Hospital, Utrecht, The Netherlands

SUMMARY Mucosal uptake, mucosal transfer, and retention of a physiological dose of ferrous $\neg$ iron were studied in women with active rheumatoid arthritis (RA): 19 with normal and 17 withir depleted bone marrow iron stores. Control subjects were 26 normal women and 20 women with uncomplicated iron deficiency. Iron absorption was measured with ${ }^{59} \mathrm{Fe}$ as a tracer and by wholeo body counting. Compared with controls, final iron retention was considerably decreased in both groups of patients with RA. Analysis of the two sequential steps of iron absorption showed that mucosal uptake was normal in iron replete patients with RA but was significantly lower ink patients with RA with depleted iron stores compared with iron deficient controls. Mucosako transfer of iron was considerably decreased in patients with RA with normal iron stores. The impaired absorption of iron in patients with active RA may delay the correction of theo haemoglobin concentration when anaemia of chronic disease is complicated by iron deficiency.

Key words: anaemia.

Active rheumatoid arthritis (RA) may be associated with 'anaemia of chronic disorders'. This anaemia is characterised by hypoferraemia, a decreased total iron binding capacity, a reduced transferrin saturation, a decreased amount of bone marrow sideroblasts, and normal or increased iron stores in the mononuclear phagocytes of the reticuloendothelial system of the bone marrow. ${ }^{1}$ The degree of anaemia corresponds with the RA activity. ${ }^{2}$ This anaemia may respond to anti-inflammatory and disease modifying therapy. In many cases iron deficiency coexists with anaemia of chronic disorders. This may result in diagnostic difficulties. ${ }^{3}$ In these cases iron treatment may raise the haemoglobin concentration only so far as iron deficiency contributes to its deficit. In that situation anaemia of chronic disorders alone can be held responsible for the remaining part of the anaemia.

In subjects without inflammation an iron absorption test may be useful to demonstrate iron deficiency. ${ }^{4}$ Absorption of a physiological amount

Accepted for publication 29 October 1987.

Correspondence to Dr J Weber, Department of Rheumatology, Hospital de Malberg GZ, Wagnerlaan 55, 6815 AD Arnhem, The Netherlands. of radioiron has only been studied in small heter $-\frac{3}{3}$ ogeneous groups of patients with RA..$^{5-7}$ In these studies a diminished absorption of iron was reported?

In the present study we investigated the absorp tion of iron in groups of women with and withoug RA and with normal and depleted reticuloendothe- 3 lial iron stores. The method used distinguishes between two steps of iron absorption: 'mucosa? uptake' (the amount of iron taken up by the mucosa 5 cells from the lumen of the gut) and 'mucosaP transfer' (the fraction of iron taken up by the mucosal cells, which is transported to the blood). These steps result in 'iron retention' (the amount of iron still present in the body 14 days after ingestion). ${ }^{9} \mathrm{~N}$

\section{Subjects and methods}

TEST SUBJECTS

Informed consent was obtained from all patients and normal subjects. All subjects were entered into the study after a medical history, a physical examination $\frac{0}{\circ}$ routine haematological tests, determination of serun iron and iron binding capacity, and sternal bone marrow aspiration. The last was not performed? however, in young normal women without clinica政 signs of iron deficiency. Serum ferritin was not use 
for estimation of iron deficiency in patients with RA because subjects with serious iron deficiency anaemia often have normal serum ferritin concentrations, though values below $60 \mu \mathrm{g} / \mathrm{l}$ usually indicate iron deficiency. ${ }^{10}$ Normal controls were included only if there was no indication of pathological blood loss, disease or previous surgery on the digestive tract, diarrhoea, chronic disease (e.g., RA, infection, malignancy), abnormal values of serum iron and iron binding capacity, or anaemia. Iron deficient controls had no chronic disease; they had no visible blood loss during the study. The criterion for iron deficiency was lack of stainable iron in the bone marrow reticuloendothelial cells.

Classical or definite RA was diagnosed according to the criteria of the American Rheumatism Association. ${ }^{11}$ RA lesions ranged from stage I to III, according to criteria adopted by the New York Rheumatism Association and the American Rheumatism Association. ${ }^{12}$

All patients with RA were treated in hospital for persisting RA activity. Patients using oral corticosteroids or corticotrophin were not admitted to the study. Nearly all patients were treated with aurothioglucose. Anti-inflammatory and other medication was stopped 24 hours before the iron absorption test and was continued 24 hours after ingestion of the iron test dose. All subjects fasted from eight hours before until two hours after intake of the test dose. RA activity was assessed according to the limited Lansbury index ${ }^{13}$ less than four days before the iron absorption study. The parameters used in this activity index are duration of morning stiffness, grip strength, Lansbury articular index, erythrocyte sedimentation rate. The scale runs from 0 to 161 units. Low grip strength can also be a result of earlier joint destruction, which means that this parameter may be overestimated in patients with longstanding disease. The patients with RA were divided into two groups: those with stainable iron in the bone marrow reticuloendothelial cells, classified as grade 1 to 3 (on a scale of 0 to 4 according to reference 14), and those with negative iron staining (grade 0); the last group was considered to be iron deficient. Table 1 summarises some haematological and activity parameters.

\section{DETERMINATION OF IRON ABSORPTION}

Mucosal uptake, mucosal transfer, and retention of iron were measured using the whole body counters of the National Institute of Public Health and Environmental Hygiene RIVM (Bilthoven) and the Radiological Service Unit TNO (Arnhem), according to methods described earlier. ${ }^{15-17}$ The oral test dose contained $1 \mathrm{mg} \mathrm{Fe}{ }^{++}$, given as ferrous ammonium sulphate, labelled-at the RIVM or TNO respectively - with 185 or $370 \mathrm{kBq}{ }^{59} \mathrm{Fe} ; 1.48$ or $0.74 \mathrm{MBq}$ ${ }^{51} \mathrm{Cr}$ was added as a non-absorbable indicator of gastrointestinal passage, and $10 \mathrm{mg}$ ascorbic acid as an antioxidant. The results of the two whole body counts were compared and were in agreement with each other.

Table 1 Haematological values and activity indices in women with active rheumatoid arthritis $(R A)$ and in controls*

\begin{tabular}{|c|c|c|c|c|}
\hline & $\begin{array}{l}\text { Normal } \\
\text { women }\end{array}$ & $\begin{array}{l}\text { Women with } \\
R A\end{array}$ & $\begin{array}{l}\text { Women with } \\
\text { uncomplicated } \\
\text { Fe deficiency }\end{array}$ & $\begin{array}{l}\text { Women with } \\
R A \text { and } \\
\text { Fe deficiency }\end{array}$ \\
\hline $\mathbf{n}$ & 26 & 19 & 20 & 17 \\
\hline Age (years) & $\begin{array}{l}53(23) \\
(19-77)\end{array}$ & $\begin{array}{l}59(18) \\
(20-78)\end{array}$ & $\begin{array}{l}42(19) \\
(16-84)\end{array}$ & $\begin{array}{l}54(19) \\
(22-85)\end{array}$ \\
\hline $\mathrm{Hb}^{\dagger}(\mathrm{g} / \mathrm{l})$ & $\begin{array}{l}147(6 \cdot 0) \\
(132-161)\end{array}$ & $\begin{array}{l}111(11) \\
(85-124)\end{array}$ & $\begin{array}{l}116(26) \\
(68-148)\end{array}$ & $\begin{array}{l}109(8 \cdot 0) \\
(90-119)\end{array}$ \\
\hline $\mathrm{MCV}^{\dagger}$ (fl) & $\begin{array}{l}93(4) \\
(84-105)\end{array}$ & $\begin{array}{l}100(4) \\
(93-110)\end{array}$ & $\begin{array}{l}81(12) \\
(61-101)\end{array}$ & $\begin{array}{l}99(3) \\
(95-106)\end{array}$ \\
\hline $\mathrm{SI}^{\dagger}(\mu \mathrm{mol} / \mathrm{l})$ & $\begin{array}{l}21(5) \\
(14-32)\end{array}$ & $\begin{array}{l}7(4) \\
(4-16)\end{array}$ & $\begin{array}{l}7(5) \\
(1-18)\end{array}$ & $\begin{array}{l}5(2) \\
(2-9)\end{array}$ \\
\hline UIBC $\dagger(\mu \mathrm{mol} / \mathrm{l})$ & $\begin{array}{l}40(9) \\
(26-56)\end{array}$ & $\begin{array}{l}38(10) \\
(21-61)\end{array}$ & $\begin{array}{l}66(16) \\
(43-95)\end{array}$ & $\begin{array}{l}55(10) \\
(39-79)\end{array}$ \\
\hline TIBC $^{+}(\mu \mathrm{mol} / \mathrm{l})$ & $\begin{array}{l}61(9) \\
(46-80)\end{array}$ & $\begin{array}{l}45(11) \\
(25-70)\end{array}$ & $\begin{array}{l}74(14) \\
(54-97)\end{array}$ & $\begin{array}{l}59(10) \\
(43-84)\end{array}$ \\
\hline Fe sat. ${ }^{\dagger}$ (fraction) & $\begin{array}{l}0.34(0.08) \\
(0.22-0.54)\end{array}$ & $\begin{array}{l}0.16(0.07) \\
(0.08-0 \cdot 35)\end{array}$ & $\begin{array}{l}0.11(0.08) \\
(0.01-0.27)\end{array}$ & $\begin{array}{l}0.08(0.03) \\
(0.04-0.17)\end{array}$ \\
\hline $\mathrm{ESR}^{+}(\mathrm{mm} / 1 \mathrm{st} \mathrm{h})$ & $\begin{array}{l}11(8) \\
(2-31)\end{array}$ & $\begin{array}{l}73(35) \\
(10-124)\end{array}$ & $\begin{array}{l}15(10) \\
(6-47)\end{array}$ & $\begin{array}{l}63(33) \\
(15-124)\end{array}$ \\
\hline $\begin{array}{l}\text { Activity index } \\
\text { (units) }\end{array}$ & ND & $\begin{array}{l}63(9) \\
(32-112)\end{array}$ & ND & $\begin{array}{l}60(7) \\
(33-83)\end{array}$ \\
\hline
\end{tabular}

${ }^{*}$ Values are mean (SD) (range).

$\dagger \mathrm{Hb}=$ haemoglobin; $\mathrm{MCV}=$ mean cell volume; $\mathrm{SI}=$ serum iron; UIBC=unbound iron binding capacity; TIBC=total iron binding capacity; $\mathrm{Fe}$-sat. =iron saturation; $\mathrm{ESR}=$ erythrocyte sedimentation rate. 


\section{OTHER METHODS}

Erythrocyte sedimentation rate was determined by the Westergren method. Haemoglobin concentration and mean cell volume were measured in a Coulter counter. Serum iron and total iron binding capacity were determined by the methods of Ramsay. ${ }^{18}{ }^{19}$ Bone marrow iron was stained by the Prussian blue reagent. Statistical significance of differences was tested with the non-parametric two tailed Wilcoxon test for independent samples. Coefficients of correlation were calculated using the STATA professional system (Computing Research Center, Los Angeles, CA).

\section{Results}

Figs 1a, b, and $\mathrm{c}$ show the remarkable differences in iron absorption found between control subjects and patients with active rheumatoid arthritis. Iron retention (Fig. 1a) had decreased in patients with active RA, both with and without stainable iron in the bone marrow reticuloendothelial cells, compared with normal and iron deficient control subjects respectively $(p<0.01)$. In iron deficient patients with RA retention of iron was higher than in those with normal iron stores $(p<0.02)$. Nine of 17 iron deficient patients with RA had iron retention values below the range of subjects with uncomplicated iron deficiency.

Analysis of the two steps in iron absorption showed that mucosal uptake of iron in patients with RA with normal bone marrow iron stores did not differ significantly from the uptake in controls $(p>0 \cdot 10)$ (Fig. 1b). Mucosal uptake was much lower in iron deficient RA patients than in subjects with uncomplicated iron deficiency $(\mathrm{p}<0.01)$.

Mucosal transfer of iron (Fig. 1c) appeared to be lower in patients with RA with normal bone marrow iron stores than in normal controls $(p<0 \cdot 01)$. In patients with RA with depleted bone marrow iron stores mucosal transfer of iron had increased considerably compared with those with normal iron stores $(p<0 \cdot 01)$ to a concentration not significantly

Fig. 1 Iron absorption values measured in women: normals, patients with active rheumatoid arthritis and normal iron stores, patients with uncomplicated iron deficiency, and patients with active rheumatoid arthritis and depleted bone marrow iron stores.

(a) Iron retention (RT); (b) mucosal iron uptake (MU);

(c) mucosal iron transfer fraction. Iron retention and mucosal iron uptake are expressed as a percentage of the initial dose of ${ }^{59} \mathrm{Fe}$ administered. Mucosal iron transfer was calculated as the ratio of iron retention and mucosal iron uptake (RT/MU). different from that in iron deficient control subjects $(\mathrm{p}>0 \cdot 10)$.

We tried to relate the iron absorption values in $\stackrel{\vec{\nexists}}{\overrightarrow{3}}$ the patients with active RA to the degree of diseaseo activity and to parameters that may be involved in을 the regulation of iron absorption (Table 2). This was
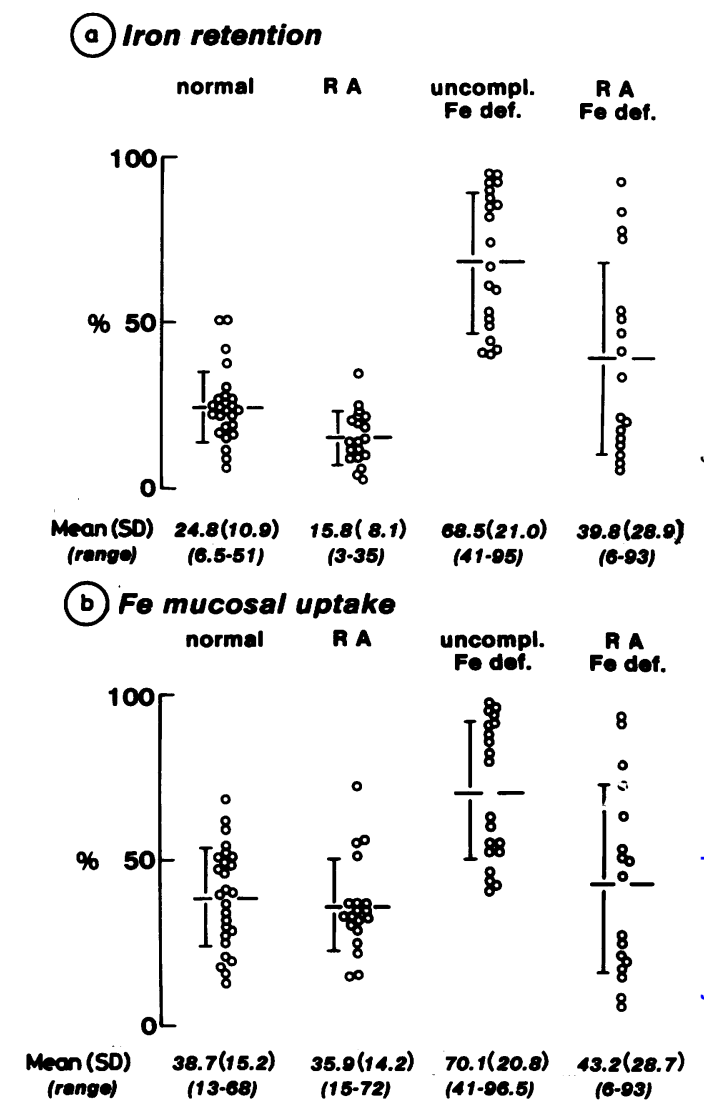

(C) Fo mucosal transfor

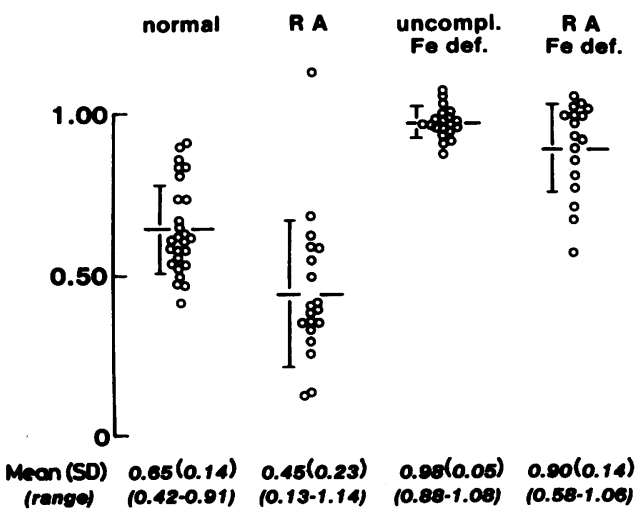


Table 2 Correlation between iron absorption and some indicators of disease activity and of the iron status in patients with active rheumatoid arthritis and in control subjects $\dagger$

\begin{tabular}{|c|c|c|c|}
\hline & Fe retention & Fe mucosal uptake & Fe mucosal transfer \\
\hline \multicolumn{4}{|c|}{$\begin{array}{l}\text { RA and } B M \ddagger \text { iron grade } 1-3 \\
(n=19)\end{array}$} \\
\hline ESR & $-0 \cdot 170$ & $0 \cdot 272$ & -0.278 \\
\hline Activity index & $-0 \cdot 155$ & 0.253 & -0.300 \\
\hline $\mathrm{Hb}$ & 0.044 & $-0 \cdot 238$ & $0 \cdot 168$ \\
\hline SI & 0.046 & -0.090 & 0.011 \\
\hline UIBC & $0.589^{* *}$ & 0.306 & $0 \cdot 280$ \\
\hline TIBC & $0 \cdot 575^{*}$ & 0.259 & $0 \cdot 269$ \\
\hline Fe saturation & $-0 \cdot 188$ & $-0 \cdot 228$ & -0.097 \\
\hline $\mathrm{BM}$ iron & $-0 \cdot 294$ & -0.082 & $-0 \cdot 129$ \\
\hline \multicolumn{4}{|c|}{$\begin{array}{l}\mathrm{RA} \text { and } \mathrm{BM} \text { iron grade } 0 \\
(\mathrm{n}=17)\end{array}$} \\
\hline ESR & $-0 \cdot 103$ & $-0 \cdot 190$ & 0.087 \\
\hline Activity index & $-0 \cdot 125$ & $-0 \cdot 169$ & -0.001 \\
\hline $\mathrm{Hb}$ & $-0 \cdot 318$ & $-0 \cdot 251$ & -0.206 \\
\hline SI & -0.199 & $-0 \cdot 122$ & -0.254 \\
\hline UIBC & 0.402 & 0.388 & 0.400 \\
\hline TIBC & $0 \cdot 376$ & 0.376 & 0.365 \\
\hline Fe saturation & -0.327 & -0.250 & -0.391 \\
\hline \multicolumn{4}{|c|}{$\begin{array}{l}\text { RA and } B M \text { iron grade } 0-3 \\
(n=36)\end{array}$} \\
\hline ESR & $-0 \cdot 159$ & $-0 \cdot 040$ & -0.204 \\
\hline Activity index & -0.134 & $0 \cdot 005$ & $-0 \cdot 212$ \\
\hline $\mathrm{Hb}$ & $-0 \cdot 199$ & $-0 \cdot 231$ & -0.061 \\
\hline SI & $-0 \cdot 251$ & $-0 \cdot 139$ & -0.325 \\
\hline UIBC & $0.586^{* * *}$ & $0.363^{*}$ & $0.655^{* * *}$ \\
\hline TIBC & $0.551^{* * *}$ & $0 \cdot 345^{*}$ & $0.605^{* * *}$ \\
\hline Fe saturation & $-0.422^{*}$ & -0.247 & $-0.532^{* * *}$ \\
\hline $\mathrm{BM}$ iron & $-0 \cdot 466^{* *}$ & $-0 \cdot 160$ & $-0 \cdot 683^{* * *}$ \\
\hline \multicolumn{4}{|c|}{$\begin{array}{l}\text { Controls with BM iron } \\
\text { grade } 0-3(n=33)\end{array}$} \\
\hline ESR & 0.086 & $0 \cdot 156$ & -0.072 \\
\hline $\mathrm{Hb}$ & $-0.591^{* * *}$ & $-0.526^{* *}$ & $-0.514^{* *}$ \\
\hline SI & $-0 \cdot 709^{* * *}$ & $-0 \cdot 614^{* * *}$ & $-0.740^{* * *}$ \\
\hline UIBC & $0.667^{* * *}$ & $0 \cdot 611^{* * *}$ & $0 \cdot 584^{* * *}$ \\
\hline TIBC & $0.574^{* * *}$ & $0 \cdot 542^{* *}$ & $0.445^{* *}$ \\
\hline $\mathrm{Fe}$ saturation & $-0.723^{* * *}$ & $-0 \cdot 646^{* * *}$ & $-0.715^{* * *}$ \\
\hline $\mathrm{BM}$ iron & $-0 \cdot 799^{* * *}$ & $-0 \cdot 724^{* * *}$ & $-0 \cdot 761^{* * *}$ \\
\hline
\end{tabular}

${ }^{*} 0.05>p>0.01 ;{ }^{* *} 0.01>p>0.001 ;{ }^{* * *} p<0.001$.

$\dagger$ The correlation coefficients for $n-2$ and their significance are indicated.

$\ddagger \mathrm{BM}=$ bone marrow; for other abbreviations see Table 1 .

done separately in patients with RA with and without positive bone marrow iron stores, because some parameters can be influenced by both disease activity and iron deficiency, and in control subjects. No significant correlation could be detected between any of the indicators of disease activity and iron absorption values.

\section{Discussion}

Iron metabolism is disturbed in states of inflammation. Even one single period of fever may produce a rapid and prolonged decrease of serum iron and an increase of serum ferritin concentration. ${ }^{20}$ The hypoferraemia may be seen as an attempt to deprive a potential pathogen of an essential growth factor. ${ }^{21}$ Remarkably hypoferraemia exists despite normal or increased bone marrow iron stores. This may be explained by sequestration of iron by tissue macrophages during inflammatory states. ${ }^{22}$ In addition, the release of iron by macrophages is blocked..$^{23}$ As a result the supply of iron for erythropoiesis may be restricted, ${ }^{24}$ and bone marrow response to anaemia may be limited by the availability of iron. ${ }^{25}$ In patients with RA the synovial membrane may sequester large amounts of iron, which may contribute to the development of anaemia. ${ }^{26}$ It is sug- 
gested that iron stores in affected joints are responsible for the relatively high concentration of serum ferritin in patients with RA, even in subjects with depleted bone marrow iron stores. ${ }^{27}$

In this study we found that absorption of iron was decreased in patients with RA, both with normal and depleted iron stores. In patients with RA with normal bone marrow iron stores mucosal uptake of iron did not differ from that in normal controls. Those with depleted iron stores, however, were unable to increase mucosal iron uptake to the same extent as patients with uncomplicated iron deficiency. As a result the absolute amount of iron transported by the mucosal cells of iron depleted patients with RA was much lower than in patients with uncomplicated iron deficiency, despite lack of difference in the mucosal transfer fraction.

Our patients with RA represented a wide range of disease activity. The complete lack of correlation between the indicators of RA activity and the absorption of iron, although iron absorption is significantly decreased in active RA, means that factors causing the decrease of iron absorption must be fully operative early during activation of RA. It was striking that depletion of bone marrow iron stores, being highly correlated with both mucosal uptake and mucosal transfer of iron in control subjects, had no influence on mucosal uptake in active RA. Further investigation should be directed to the production of iron carriers in the microvillus membrane and cytosol of mucosal cells, which apparently do not react on development of iron deficiency elsewhere in the body. The transfer of iron from the mucosal cell to the plasma is correlated with the availability of free transferrin iron binding sites, probably best represented by the unbound iron binding capacity. The difference in mucosal transfer between controls and patients with active RA may be the result of an absolute decrease of circulating transferrin or of a decreased turnover of free binding sites. For better assessment of these factors a combination of iron absorption with ferrokinetic studies is needed. Also, submucosal tissue macrophages may act as a trap during passage of iron to the plasma. ${ }^{28}$

In our two groups of patients with RA, with and without iron deficiency, the mean haemoglobin concentrations were virtually identical. We suppose, however, that the decreased iron retention will, in the long run, contribute to the development or persistence of iron deficiency anaemia in patients with RA. If the same mechanisms operate for therapeutic iron administration the correction of iron deficiency in patients with RA by oral iron treatment may be more difficult and time consuming than in patients with uncomplicated iron deficiency.
This study was supported by grants from the Organisation for $\square$ Applied Scientific Research TNO and the Netherlands Rheumatism Association.

\section{References}

1 Cartwright G E. The anemia of chronic disorders. Semin Hematol 1966; 3: 351-75.

2 Engstedt L, Strandberg O. Hematological data and clinical $\frac{\mathcal{S}}{7}$ activity of the rheumatoid disease. Acta Med Scand [Suppl] 1966; 454: 13-29.

3 Cartwright G E, Lee G R. The anaemia of chronic disorders. $B r$ J Haematol 1971; 21: 147-52.

4 Heinrich H C. Intestinal iron absorption in man. Methods of measurement, dose relationship, diagnostic and therapeutic $\vec{\omega}$ applications. In: Hallberg L, Harwerth H-G, Vannotti A, eds. Iron deficiency. London and New York: Academic Press, 1970: 213-96.

5 Boddy K, Will G. Iron absorption in rheumatoid arthritis. Ann Rheum Dis 1969; 28: 537-40.

6 Roberts F D, Hagedorn A B, Slocumb C H, Owen C A. G Evaluation of the anemia of rheumatoid arthritis. Blood 1963; 21: $470-8$

7 Vas M R, De Leeuw N K M. Iron absorption in patients with 윽 rheumatoid arthritis and in normal subjects. Can Med Assoc $\mathrm{J}=$ 1967; 97: 504-9.

8 Wheby M S, Jones L R G, Crosby W H. Studies on iron absorption. Intestinal regulatory mechanisms. J Clin Invest 1964; 43: 1433-42.

9 Boender C A, Mulder E, Ploem J E, De Wael J, Verloop $\infty$ M C. Iron absorption and retention in man. Nature 1967; 213: 1236-7.

10 Hansen T M, Hansen N E, Birgens H S, Hølund B, Lorenzen I. Serum ferritin and the assessment of iron deficiency in rheumatoid arthritis. Scand J Rheumatol 1983; 12: 353-9.

11 Ropes M W, Bennett G A. Cobb S, Jacox R, Jessar R A. Revision of diagnostic criteria for rheumatoid arthritis. Arthritis $\mathbb{Q}$ Rheum 1959: 2: 16-20.

12 Steinbrocker O, Traeger C H, Batterman R C. Therapeutic criteria in rheumatoid arthritis. JAMA 1949; 140: 659-62.

13 Lansbury J. Report of a three-year study on the systemic and articular indexes in rheumatoid arthritis. Arthritis Rheum 1958;무 1: $505-22$.

14 Ploem J E, De Wael J, Verloop M C, Punt K. Sideruria following a single dose of desferrioxamine-B as a diagnostic test in iron overload. Br J Haematol 1966; 12: 396-408.

15 Flendrig J A, Van Tongeren J H M, Hogeweg B, Verhoef C W. Aspects of iron absorption and iron retention, especially in $\bigcirc$ patients with idiopathic haemochromatosis. In: Fellinger $\mathrm{K}, 3$ Hoefer R, eds. Radioaktive Isotope in Klinik und Forschung, $\mathrm{O}$ Vol. VIII. Muenchen, Berlin, Wien: Urban and Schwarzenberg, 1968: $138-49$.

16 Marx J J M. Mucosal uptake, mucosal transfer and retention of iron measured by whole-body counting. Scand J Haematol 1979; 23: 293-302.

17 Marx J J M, van den Beld B, van Dongen R, Strackee L H. Simultaneous measurement of ${ }^{59} \mathrm{Fe}$ and ${ }^{51} \mathrm{Cr}$ in iron absorption $\mathrm{O}$ studies using a whole-body scanner with mobile shielding. Nuklearmedizin 1980; 19: 140-5.

18 Ramsay W N M. The determination of iron in blood plasma or serum. Clin Chim Acta 1957; 2: 214-20. 19 Ramsay W N M. The determination of the total iron-binding
capacity of serum. Clin Chim Acta 1957; 2: 221-6.

20 Elin R J, Wolff S M. Finch C A. Effect of induced fever on $\square$ serum iron and ferritin concentration in man. Blood 1977; 49:147-53.

21 Blake D R, Waterworth R F, Bacon P A. Assessment of iron stores in inflammation by assay of serum ferritin concentrations. Br Med J 1981; 283: 1147-8.

22 Crosby W H. Iron and the macrophage. Arch Intern Med 1982, 142: 233-5.

\section{.} . 
23 Esparza 1. Brock J H. Release of iron by resident and stimulated mouse peritoncal macrophages following ingestion and degradation of transferrin-antitransferrin immunc complexes. Br J Haematol 1981: 49: 6(1)3-14.

24 Lee C R. The anemia of chronic discasc. Semin Hematol 1983: 20: $61-80$.

25 Douglas S W, Adamson J W. The anemia of chronic disorders: studies of marrow regulation and iron metabolism. Blood 1975: 40: $55-65$.
26 Muirden K D. The anacmia of rheumatoid arthritis: the significance of iron deposits in the synovial membranc. Australasian Annals of Medicine 1970; 2: 97-1(14.

27 Bayncs R D. Bothwell T H. Bezwoda W R. Gcar A J. Atkinson P. Hematological and iron-related measurements in rheumatoid arthritis. Am J Clin Pathol 1986; 87: 196-200.

28 Refsum S B. Schreiner B. Iron excretion from the goblet cells of the small intestine in man. Scand J Gastroenterol 1980): 15: 1013-20. 